\title{
VAMOS À HISTÓRIA DOS SUBÚRBIOS: UMA LEITURA ESPACIAL DO ROMANCE DOM CASMURRO, DE MACHADO DE ASSIS
}

\section{VAMOS A LA HISTORIA DE LOS SUBURBIOS: UNA LECTURA ESPACIAL DEL ROMANCE DOM CASMURRO, DE MACHADO DE ASIS}

\section{ALLONS À L'HISTOIRE DES BANLIEUES: UNE LECTURE SPATIALE DU ROMAN DOM CASMURRO, DE MACHADO DE ASSIS}

\author{
Adriana Carvalho Silva ${ }^{1}$ \\ Universidade Federal Rural do Rio de Janeiro, Seropédica, Brasil
}

\begin{abstract}
Resumo: Considerando o romance como resultado de uma relação que implica sujeito (autor), espaço e narrativa, partimos da hipótese de que Machado de Assis, através de recursos narrativos, qualifica a cidade do Rio de Janeiro e, particularmente, o subúrbio carioca, em Dom Casmurro. O romance é analisado sob o conceito da ambientação desenvolvido por Osman Lins, o que permitiu que novos elementos fizessem parte da composição do espaço geográfico investigado, a exemplo do leitor, das diversas "lacunas" do texto, das analogias e intertextualidades.
\end{abstract}

Palavras-chave: Espaço; literatura; sujeito.

Résumé: En considérant le roman comme le résultat d'une relation qui implique le sujet (l'auteur), l'espace et la narration, nous sommes partis de l'hypothèse que Machado de Assis, à travers des recours narratifs, qualifie la ville de Rio de Janeiro et, particulierement, la périphérie de la ville de Rio de Janeiro, en Dom Casmuro. Le roman est analisé sous le concepte de l'ambience développée par Osman Lins, ce qui a permis que de nouveaux éléments fassent partie de la composition de l'espace géographique étudié, comme par exemple, le lecteur, les diverses lacunes du texte, des analogies et des intertextualités.

Mots-clé: espace; littérature; sujet.

Resumen: Considerando la novela como el resultado de una relación implicando el individuo (el autor), el espacio y la narración, partimos de la hipótesis que Machado de Assis, a través de recursos narrativos, califica la ciudad de Rio de Janeiro, como Dom Casmuro. La novela es analizada bajo el concepto del ambiente criado por Osman Lins, lo que permitió que nuevos elementos hagan parte de la composición del espacio geográfico, como por ejemplo, el lector, las varias lagunas del texto, las analogias y intertextualidades.

Palabras-clave: espacio; literatura; individuo.

\footnotetext{
${ }^{1}$ Adriana Carvalho Silva é doutora em Geografia pela Universidade Federal Fluminense (UFF) em 2012 com a tese $O$ Rio de Janeiro em Dom Casmurro: literatura como representação do espaço.
} 


\section{INTRODUÇÃO}

Uma cidade é um corpo de pedra com um rosto. O rosto da cidade fluminense é esta rua, rosto eloquente que exprime todos os sentimentos e todas as ideias.

(ASSIS, Jornal das Famílias, 1873).

O trecho citado acima, extraído de um conto de Machado Assis, situa-nos no Rio de Janeiro do final do século XIX, uma cidade Capital do Império que concentra em uma única rua, a Rua do Ouvidor, o símbolo mais representativo da atmosfera urbana desejada. Que imagens e representações se constroem sobre o espaço dessa cidade a partir desta rua?

A universalidade da literatura machadiana tinha um contraponto local e este era, sem dúvida, o Rio de Janeiro, cidade em que Machado de Assis nasceu e viveu toda sua vida, escreveu seus romances e crônicas. Embora Machado não tenha privilegiado uma descrição do espaço físico como o fizeram outros escritores de seu tempo, a exemplo de Aluísio Azevedo ou José de Alencar, razão pela qual se atribuiu a ele uma "ausência" de referenciais espaciais, podemos afirmar que a ambientação está presente na obra machadiana, sobretuto em Dom Casmurro, livro que ficou conhecido como o nosso Otelo, no qual o narrador nos conta suas memórias desde os tempos de infância quando era vizinho de Capitu na Rua Matacavalos, situada na freguesia central do Rio de Janeiro do século XIX.

Por ambientação consideramos a contribuição teórica de Osman Lins (1976), romancista brasileiro que ao pesquisar o espaço romanesco em Lima Barreto lançou importantes reflexões teóricas sobre as relações entre o espaço e a narrativa. Valemo-nos da distinção sugerida por Lins (1976) entre espaço e ambientação na intenção de trazer a ótica para o romance Dom Casmurro, de Machado de Assis:

Por ambientação, entenderíamos o conjunto de processos conhecidos ou possíveis, destinados a provocar, na narrativa, a noção de um determinado ambiente. Para a aferição do espaço, levamos a nossa experiência do mundo; para ajuizar sobre a ambientação, onde transparecem os recursos expressivos do autor, impõe-se um certo conhecimento da arte narrativa (LINS, 1976, p. 77).

Lins, que ainda diferencia três tipos de ambientação (a franca, a reflexiva e a dissimulada), ou seja, três modos de articular espaço e ação, que normalmente vão se intercalar para compor um romance, defende que a ambientação às vezes requer uma atenção redobrada do leitor, pois o espaço pode nascer "dos gestos e ações da personagem" (LINS, 1976, p.83). Em acordo com Lins, devemos reconhecer então que a análise geográfica do texto machadiano apoiada apenas na descrição do espaço físico e no arranjo sócio-espacial da cidade - levantando os espaços geográficos descritos no texto e suas correspondências com os 
espaços reais da cidade - seria um tanto periférica. O romance Dom Casmurro poderia, sim, dar-nos um panorama da cidade do Rio de Janeiro na época em que foi escrito, mas essa perspectiva pouco nos revelaria de profundo ou novo sobre o espaço geográfico da cidade do Rio de Janeiro.

No entanto, se olharmos o romance Dom Casmurro pelo viés da ambientação, a coisa muda. Todos os elementos do texto passam a participar do quadro que compõe a cidade, como o leitor e as estratégias narrativas, as personagens e suas ações, e, sobretudo, a relação entre ação e espaço. Sob tal perspectiva, temos um Rio de Janeiro que nasce da experiência e da imaginação (do autor e do leitor), e que é a conjunção dos mitos urbanos modernos (a cidade ideal e a cidade imoral) com os mitos e obras invocados pelo autor.

Para construir o espaço do romance, Machado de Assis não recorre a uma descrição simples e direta, ele ambienta uma trama construída através das metáforas e intertextualidades buscadas no universo dos mitos, na Bíblia, nos clássicos da literatura universal e, ainda, no imaginário social. O leitor, diante de Dom Casmurro, precisa estar atento para perceber a dimensão espacial do texto. Desfruta melhor o romance aquele leitor que conhece de antemão a cidade do Rio de Janeiro do final do século XIX e isto se deve a dois motivos: em primeiro lugar, ajuda a desvendar as referências espaciais sutis do texto na construção espacial da trama, e, em seguida, coloca-o em vantagem para seguir as pistas que o narrador vai deixando ao longo do texto, uma estratégia narrativa do bruxo do Cosme Velho muito bem descrita por Marta de Senna (2008[1999]) no texto Estratégias de embuste: Dom Casmurro:

Entre os romances de Machado de Assis, Dom Casmurro é, talvez, aquele em que se exerce com maior vigor uma das suas mais interessantes estratégias narrativas. Refiro-me ao que chamo de estratégia de embuste, ou seja, aquela através da qual o narrador machadiano se compraz em construir, quase a cada página, um trompe l'oeil que condiciona o olhar do leitor a ver o que não é, a não ver o que é (SENNA, 2008, p. 79).

\section{VAMOS À HISTÓRIA DOS SUBÚRBIOS}

Dom Casmurro inicia-se com o narrador explicando o título do livro. Um conhecido do bairro que viajara com ele de trem deu-lhe esse apelido após um episódio em que o narrador cochilara no momento em que o outro lia seus poemas durante o percurso, “(...) como eu estava cansado, fechei os olhos três ou quatro vezes; tanto bastou para que ele interrompesse a leitura e metesse os versos no bolso" (ASSIS, 2008, p. 931). Frustrado, o poeta guardou os versos e criou o apelido. A viagem era pela Estrada de Ferro D. Pedro II (que passou a chamar-se Estrada de Ferro Central do Brasil após novembro de 1889). Explicado o título, o narrador, no entanto, nada diz sobre os motivos que o levaram a escolher 
o Engenho Novo para morar, apenas revela a razão pela qual reproduziu nesse bairro a casa de sua infância situada na Rua de Matacavalos, quando era vizinho de Capitu: "O meu fim evidente era atar as duas pontas da vida, e restaurar na velhice a adolescência. Pois senhor, não consegui recompor o que foi nem o que fui” (ASSIS, 2008, p. 932).

Há uma distância temporal e espacial entre Bentinho e Dom Casmurro, que insinua a metamorfose sofrida pelo narrador. O Bentinho da Rua Matacavalos ficou somente na memória de Dom Casmurro, "homem calado e metido consigo mesmo", uma vez que todos os demais envolvidos na trama estavam mortos, "todos os antigos foram estudar a geologia dos campos santos" (ASSIS, 2008, p.932). A casa da infância reproduzida em réplica anos depois, situa o narrador num simulacro, um cenário criado a partir de suas memórias:

Construtor e pintor entenderam bem as indicações que lhes fiz: é o mesmo prédio assobradado, três janelas de frente, varanda ao fundo, as mesmas alcovas e salas. Na principal destas, a pintura do teto e das paredes é mais ou menos igual, umas grinaldas de flores miúdas e grandes pássaros que as tomam nos bicos, de espaço a espaço. Nos quatro cantos do teto as figuras das estações, e ao centro das paredes os medalhões de César, Augusto, Nero e Massinissa, com os nomes por baixo... Não alcanço a razão de tais personagens. Quando fomos para a casa de Matacavalos, já ela estava assim decorada; vinha do decênio anterior. Naturalmente era gosto do tempo meter sabor clássico e figuras antigas em pinturas americanas. $\mathrm{O}$ mais tudo é análogo e parecido. Tenho chacarinha, flores, legume, uma casuarina, um poço e lavadouro. Uso louça velha e mobília velha. Enfim, agora como outrora, há aqui o mesmo contraste da vida interior, que é pacata, com a exterior que é ruidosa (ASSIS, 2008, p. 932).

Quase no fim do romance o narrador revela porque não ficou morando na casa da Rua de Matacavalos depois que sua mãe falecera. Se a casa ainda existia, na mesma rua antiga, por que, então, recriá-la longe dali? O fato é que o narrador diz não existir mais uma identificação entre ele e a casa, eles não se reconheceram. Apesar das referências espaciais concretas terem se mantido (a rua e a casa da família Santiago), o único espaço onde existia a trama de Bentinho e Capitu era na memória do narrador:

Hão de perguntar-me por que razão, tendo a própria casa velha, na mesma rua antiga, não impedi que a demolissem e vim reproduzi-la nesta. A pergunta devia ser feita a princípio, mas aqui vai a resposta. A razão é que, logo que minha mãe morreu, querendo ir para lá, fiz primeiro uma longa visita de inspeção por alguns dias, e toda casa me desconheceu. No quintal a aroeira e a pitangueira, o poço, a caçamba velha e o lavadouro, nada sabia de $\mathrm{mim}$. A casuarina era a mesma que eu deixara ao fundo, mas o tronco, em vez de reto, como outrora, tinha agora um ar de ponto de interrogação; naturalmente pasmava do intruso. Corri os olhos pelo ar, buscando algum pensamento que ali deixasse, e não achei nenhum. Ao contrário, a ramagem começou a sussurrar alguma coisa que não entendi logo, e parece que era a cantiga das manhãs novas. Ao pé dessa música sonora e juvenil, ouvi também o grunhir dos porcos, espécie de troça concentrada e filosófica. 
Tudo me era estranho e adverso. Deixei que demolissem a casa, e, mais tarde, quando vim para o Engenho Novo, lembrou-me fazer essa reprodução por explicações que dei ao arquiteto segundo contei em tempo (ASSIS, 2008, p. 1069).

A narrativa, a partir da casa réplica daquela de sua infância como vizinho de Capitu, é o relato do sujeito situado fora do núcleo urbano, espaço onde o romance de Bento e Capitu ocorrera, um espaço irrecuperável. A casa reproduzida não é capaz de devolver a Dom Casmurro o que ele foi enquanto Bentinho. Mas, e o Engenho Novo? Que significados pode assumir esse espaço onde se reproduz o cenário "vazio" da trama? Vejamos as duas únicas referências no texto sobre o Engenho Novo: a primeira é no capítulo um, quando o narrador nos conta como seus amigos assimilaram seu apelido, "Vou para Petrópolis, Dom Casmurro; a casa é a mesma da Renânia; vê se deixas essa caverna do Engenho Novo, e vai lá passar uns quinze dias comigo" (ASSIS, 2008, p. 931); a segunda é no capítulo oitenta e cinco, quando ele faz uma digressão:

Suspendamos a pena e vamos à janela espairecer a memória. Realmente o quadro era feio, já pela morte, já pelo defunto, que era horrível... Isto aqui, sim, é outra coisa. Tudo o que vejo lá fora respira vida, a cabra que rumina ao pé de uma carroça, a galinha que marisca no chão da rua, o trem da Estrada Central que bufa, assobia, fumega e passa, a palmeira que investe para o céu, e finalmente aquela torre de igreja, apesar de não ter músculos nem folhagem. Um rapaz que ali do beco empina um papagaio de papel, não morreu nem morre, posto que se chame Manduca (ASSIS, 2008, p. 1019).

A ideia de que o Engenho Novo pode representar um espaço de reclusão e isolamento encontra apoio em alguns trechos do romance que contam o cotidiano do narrador: o primeiro no início do romance, "Em verdade pouco apareço e menos falo. Distrações raras. O mais do tempo é gasto em hortar, jardinar e ler; como bem e não durmo mal" (ASSIS, 2008, p. 932); outro já quase no fim do romance, "Tenho-me feito esquecer. Moro longe e saio pouco". Contudo, o Engenho Novo não configura exatamente um isolamento, se observarmos outros trechos como os três a seguir: "Entretanto vida diferente não quer dizer vida pior" (ASSIS, 2008, p. 932); “Apesar de tudo jantei bem e fui ao teatro" (ASSIS, 2008, p. 1071), diz Dom Casmurro, depois de receber a notícia da morte de seu filho Ezequiel; no penúltimo capítulo: “Já sabes que a minha alma, por mais lacerada que tenha sido, não ficou aí para um canto como uma flor lívida e solitária. Não lhe dei essa cor ou descor. Vivi o melhor que pude, sem me faltar amigas que me consolassem da primeira" (ASSIS, 2008, p. 1072). Ao Engenho Novo, cabe investigarmos outra perspectiva que não é a de isolamento, ou pelo menos, não só.

O livro começa e termina falando da intenção do narrador em escrever uma história sobre os subúrbios: "Depois pensei em fazer uma História dos subúrbios, menos seca que as 
memórias do padre Luís Gonçalves dos Santos, relativas à cidade; era obra modesta, mas exigia documentos e datas, como preliminares, tudo árido e longo" (ASSIS, 2008, p. 932); no início do livro, e, depois, no último capítulo, “A terra lhes seja leve! Vamos à História dos subúrbios.” (ASSIS, 2008, p. 1072). Esse afastamento de Dom Casmurro do núcleo central da cidade não assume no livro o sentido de uma decadência econômica por parte do narrador, uma vez que Bento Santiago é um homem de posses, vive confortavelmente e, tradicional como parece, não haveria de escolher um bairro como Botafogo para morar, espaço comumente destinado aos nouveau riches nos romances machadianos. Além disso, o Engenho Novo não recebe nenhuma descrição no romance que tivesse tal sentido, nem tampouco qualquer outra qualificação. $\mathrm{O}$ primeiro parágrafo do romance, aquele em que o narrador explica o título do livro, apresenta uma ideia sutil sobre a distância entre o Engenho Novo e o núcleo central da cidade que pode ser percebida pelo tempo da viagem: "Uma noite destas, vindo da cidade para o Engenho Novo (...). A viagem era curta, e os versos pode ser que não fossem inteiramente maus." (ASSIS, 2008, p. 931). Notemos que essa ideia se opõe àquela do capítulo cento e quatorze comentada no parágrafo anterior: "Moro longe e saio pouco" (ASSIS, 2008, p. 1069), que traz a sensação de isolamento e distância do núcleo central.

Ao leitor cabe interpretar o significado que o Engenho Novo pode assumir na trama. Embora a culpa ou inocência de Capitu tenha assumido um ponto central no romance, outros elementos que parecem periféricos, pedem a atenção do leitor mais interessado. O Engenho Novo pode tanto significar um exílio, de onde temos um narrador defunto, enterrado em suas memórias, ou pode, ainda, representar a escolha de um espaço que abriga tanto a tranquilidade dos casarões e chácaras, como também garante a proximidade de teatros e do jockey. Essa observação não significa que pretendemos medir o grau de solidão e isolamento de Bento Santiago, mas sim avaliar que sentido podem ter as referências espaciais do texto, como elas se comunicam com o leitor e compõem um imaginário sócio-espacial presente no século XIX.

Podemos buscar alguma resposta analisando o que era o Engenho Novo enquanto “espaço real” em 1899, mas se acreditarmos que Dom Casmurro é este narrador defunto que vive isolado e mergulhado em suas memórias, será mais adequada a versão do espaço de exílio. Exilado ou confortavelmente instalado num casarão com chácara, nas proximidades do jockey club? O leitor é induzido a considerar a ambientação e tomar suas próprias conclusões. Essa característica da literatura de Machado em provocar o leitor com sua narrativa trompe l'oeil ou, simplesmente, de embuste, como aponta Senna (2008), pode permitir uma perspectiva mais viva para o subúrbio carioca. 
Uma História dos subúrbios, "menos seca que as memórias do padre Luís Gonçalves dos Santos" (ASSIS, 2008, p. 932), esse era o livro que pretendia escrever o narrador antes de pensar nas suas memórias. O padre Gonçalves dos Santos (1767- 1844), conhecido com o padre Perereca, é autor de Memória para Servir à História do Reino do Brasil, sua obra mais conhecida, um livro de memórias onde o padre Gonçalves descreve como testemunha a chegada da Família Real. O livro, oferecido a D. João VI, é escrito em 1821 na Corte do Rio de Janeiro, sendo dividido em três épocas, da felicidade, da honra e da glória. Englobando o período de 1608 a 1821, ele inclui, além da chegada da Família Real, um detalhado relato sobre a vida pública do Rio de Janeiro, a política, a parte administrativa, a vida eclesiástica, os assuntos militares e econômicos.

Dom Casmurro também é um livro de memórias, mas não diretamente implicado nas atividades políticas, diplomáticas e cerimoniais da Corte, como o livro do padre Perereca. O romance de Machado de Assis é sobre a vida privada de Bento Santiago, uma trama doméstica que, embora seja evidente que possui uma dimensão mais ampla, envolve elementos que se referem à vida social e política do país, que serão interpretados de acordo com a receptividade do leitor, ou seja, deve-se estar atento para perceber as simbologias e analogias que sustentam as mensagens do livro. De acordo com Schwarz (1991), predominaram três leituras ou interpretações de Dom Casmurro entre a crítica literária desde a aparição do livro: primeiro veio a leitura romanesca (de composição e decomposição de um amor); em segundo, a patriarcal policialesca (aquela que procura os indícios do crime de adultério de Capitu); e, ainda, uma terceira, que coloca Bento Santiago no centro do enredo, levando em conta todos os indícios sobre a sociedade do tempo em que se passa a história (é a inversão do rumo da desconfiança). Durante muito tempo predominou a leitura romanesca até que Dom Casmurro começasse a ser visto no século XX como uma obra "aberta", que exige do leitor a tarefa de tirar suas próprias conclusões. A que conclusões podemos chegar sobre o significado ou significados que o Engenho Novo pode assumir?

Os limites atuais do bairro do Engenho Novo não são de acordo com o que ele representava no final do século XIX ${ }^{2}$, ou seja, quando Machado de Assis refere-se ao Engenho Novo, não podemos imaginá-lo com os referenciais de hoje. A delimitação atual dos bairros da cidade do Rio de Janeiro é desenvolvida somente no século XX, e mesmo o

\footnotetext{
${ }^{2}$ A delimitação do bairro do Engenho Novo data, de acordo com as informações da prefeitura, do decreto $\mathrm{n}^{\circ}$ 3158 de 23 de julho de 1981, tendo o Engenho Novo sofrido nova delimitação dada pela Lei Complementar $n^{\circ}$ 17, de 29 de julho de 1992. Bairros do Município do Rio de Janeiro. Prefeitura do Rio de Janeiro, 1981.
} 
conceito de bairro foi ganhando corpo mais tarde. Segadas Soares (1990) explica a diferença entre a noção popular de bairro e a unidade administrativa:

A noção de bairro é uma noção de origem popular, tirada da linguagem corrente. Para o habitante de uma cidade, o bairro constitui no interior da mesma, um conjunto que tem sua própria originalidade. Apesar da administração municipal se aproveitar muitas vezes dessa noção para com ela rotular as circunscrições administrativas em que a cidade está dividida, não há, na maioria dos casos, coincidência entre a noção popular de bairro e as pequenas unidades administrativas ou fiscais (SEGADAS SOARES, 1990, p. 105).

Convém considerarmos que, naquela época, muitas referências espaciais estavam embasadas na divisão do território em freguesias ${ }^{3}$. As terras da freguesia do Engenho Novo foram ocupadas pelos jesuítas a partir da doação da Sesmaria do Iguaçu feita por Estácio de Sá. Os padres instalaram na respectiva Sesmaria três engenhos de açúcar (o estabelecimento Engenho Velho, o Engenho Novo e o de São Cristóvão), na região que englobava as freguesias do Engenho Velho, Engenho Novo e Inhaúma, “A antiga e importante fazenda do Engenho Novo foi de exclusiva propriedade dos padres do Colégio do Rio de Janeiro da Companhia de Jesus (...)" (SANTOS, 1965, p. 37).

O livro As Freguesias do Rio Antigo (vistas por Noronha Santos), organizado por Paulo Berger, em 1965, reúne o material levantado por Noronha Santos sobre as freguesias do Rio de Janeiro no ano de 1900. As anotações do historiador revelam uma cidade composta por 21 freguesias $^{4}$. O autor relata que a freguesia do Engenho Novo foi criada em 1873, desmembrada de parte da freguesia do Engenho Velho, da de São Cristóvão e da de S. Tiago de Inhaúma. Noronha Santos informa-nos as condições da freguesia do Engenho Novo no ano de 1900:

Tem a freguesia iluminação pública, água encanada, esgoto e possui poucas ruas calçadas a paralelepípedos. Grande parte do território da freguesia do Engenho Novo é montanhoso. Seu clima é saudável e recomendado por muitos médicos para doentes de moléstias pulmonares. Nos meses de verão os dias são geralmente quentes, porém, as noites são agradabilíssimas pela viração que sempre sopra.

\footnotetext{
${ }^{3}$ Paulo Berger nos esclarece sobre a organização do território da Capital no século XIX : "A cidade do Rio de Janeiro, nos seus primórdios, era dividida sob um aspecto eclesiástico em diversas freguesias ou paróquias, as quais se limitaram os territórios de jurisdição religiosa, em princípio. Depois essas mesmas freguesias passaram a abranger os territórios de jurisdição administrativa.” (Berger, introdução in SANTOS. As Freguesias do Rio Antigo vistas por Noronha Santos, Rio de Janeiro: o Cruzeiro, 1965, p.7)

${ }^{4}$ As vinte e uma freguesias que formavam o Rio de Janeiro em 1889 detalhadas no livro As Freguesias do Rio Antigo, com o material reunido por Noronha Santos em 1900, estão colocadas a seguir com o respectivo ano de criação: Candelária (1634), Irajá (1644), Jacarepaguá (1661), Campo Grande (1673), Ilha do Governador (1710), Inhaúma (1749), São José (1751), Santa Rita (1751), Guaratiba (1755), Engenho Velho (1762), Ilha de Paquetá (1769), Lagoa (1809), Santana (1814), Sacramento (1826- em substituição à de S. Sebastião), Santa Cruz (1834), Glória (1834), Santo Antônio (1854), São Cristóvão (1856), Espírito Santo (1856), Engenho Novo (1873), Gávea (1873).
} 
Situados nas melhores ruas da freguesia, encontramos belos prédios, de custosas construções e grandes chácaras com arvoredos frutíferos à linha da Estrada de Ferro Central do Brasil. Há quarenta anos passados pouco valia o Engenho Novo; era um povoado da cidade do Rio de Janeiro, sem importância, retalhado por fazendolas e sítios de austeros senhores de escravos. Hoje tudo está mudado, os progressos materiais fazem-se sentir por toda parte, movimentando o povo nos seus projetos de iniciativa particular; é chegada a época dignificadora do esforço individual, tanto para o pobre como para o rico, que lutam pela existência, sem os preconceitos do escravismo, que em nossa terra tudo destruiu, sem nada ter conseguido de justo e humano.

Separado ou desmembrado em parte o território desta freguesia, do Engenho Velho, S. Cristóvão e S. Tiago de Inhaúma, depois de ser criada a paróquia, pela Lei do governo Imperial no 2335 de 2 de agosto de 1873 (...), começou a progredir consideravelmente o bairro do Engenho Novo, edificando vários moradores abastados boas casas em substituição aos esquisitos prédios do tempo dos jesuítas, alguns dos quais ainda existem arruinados, como lembrança desses padres, que forma os donos e senhores absolutos da cidade (SANTOS, 1965:36-37).

Nota-se que Noronha Santos vincula os melhoramentos da região aos esforços da iniciativa privada. O desenvolvimento do bairro do Engenho Novo deve ser considerado em conjunto com outros bairros que formavam essa freguesia. O autor situa os bairros limítrofes ao Engenho Novo através das estações de trem: Mangueira, São Francisco Xavier, Rocha, Riachuelo, Sampaio, Méier, Todos os Santos e Benfica. Vejamos como a freguesia era servida pelos meios de transporte e, ainda, quais eram os seus atrativos culturais:

É servida a freguesia pelos trens das Estradas de Ferro Central do Brasil, Melhoramentos do Norte e do Rio d'Ouro; pelas duas linhas de bondes da Companhia Ferro Carril Vila Isabel - Engenho Novo, Engenho Novo - Vila Isabel e seção de Caxambi, para Inhaúma, Jacaré, Glória, Boca do Mato, Méier e S. Francisco Xavier e pela linha circular Pedregulho e Benfica, da Companhia de São Cristóvão.

A Estrada de Ferro Central do Brasil tem no território da freguesia oito estações de parada: Mangueira, S. Francisco Xavier, Rocha, Riachuelo, Sampaio, Engenho Novo, Méier e Todos os Santos. (...) Da estação de S. Francisco Xavier partem os trens da Estrada do Norte que viajam para Petrópolis (...). A Estrada de Ferro do Rio d'Ouro percorre cinco quilômetros de território da freguesia, ficando em Benfica uma das estações de parada.

O prado de corridas denominado Jockey Club, o mais antigo de todos os existentes no Rio de Janeiro, está situado na estação de S. Francisco Xavier, ocupando vastíssimo terreno (...).

Na rua D. Ana Néri, em frente a estação do Riachuelo e próximo à rua Flack, existe o elegante prédio do teatro do Riachuelo, propriedade de uma associação particular (Teatro da Sociedade Recreio Dramático Riachuelense, inaugurado em 1877 ... Possuía 28 camarotes além de uma vasta plateia e excelente palco, com cenário de autoria do artista alemão $B$. Weigand) (SANTOS, 1965, p. 34-36). 
Noronha Santos, nos levantamentos sobre a freguesia do Engenho Novo, traz uma informação que ele não desenvolve e que, aparentemente, parece desvinculada do corpo do texto: "De 1808 a 1823 estiveram acampados no Engenho Novo corpos portugueses da Divisão Auxiliadora e forças brasileiras dedicadas à causa da Independência Nacional" (NORONHA SANTOS, 1965, p.37). Esse pequeno parágrafo que antecede a informação de que havia antes de 1834, um "grande matadouro de gado bovino nas terras do Riachuelo" 5, e que passa quase despercebido no texto, projeta o Engenho Novo como uma outra referência espacial sutil em Dom Casmurro sobre o episódio político de Proclamação da Independência do Brasil.

Não podemos alcançar exatamente as razões que levaram Machado de Assis a escolher o Engenho Novo para abrigar o viúvo Dom Casmurro e suas memórias, o romance não dá essa informação e esse também não é nosso objetivo. Para nós, captar a carga simbólica do Engenho Novo no texto ajuda-nos a refletir sobre a espacialidade do romance Dom Casmurro.

Podemos perceber que a noção de subúrbio presente em Machado de Assis difere daquela que a identifica como moradia das classes desfavorecidas, como foi difundida, por exemplo, por Lima Barreto, um pouco mais tarde. Dom Casmurro insinua um espaço habitado por antigas fazendas e sítios, um vestígio da metade do século XIX, quando a região contava com "numerosos solares na Tijuca, no Engenho Velho, no Andaraí, e mesmo no Engenho Novo" (ABREU, 1987, p.63 apud BERNARDES, 1959, p.37). Um pouco do que foi o glamour dos subúrbios também pode ser percebido em Noronha Santos quando ele escreve sobre a freguesia do Engenho Velho em 1900: "Bons prédios de apurado gosto, têm sido, de 1870 para cá, construídos nas ruas servidas pelos bondes das Companhias de São Cristóvão e Vila Isabel (...) que antes daquela data só possuía casas de recreio e de campo" (NORONHA SANTOS, 1965, p.42). Abreu (1987), analisando a expansão urbana favorecida pelas companhias de transporte comenta: "não só os bairros proletários das freguesias de Santana e Espírito Santo (...) como também os ricos bairros de chácaras da zona norte (Tijuca, Andaraí), que agora estavam fadadas a desaparecer" (ABREU, 1987, p.45). Ainda sobre as áreas fora do núcleo central, Maurício Abreu confirma a importância de São Cristóvão, "Durante algum tempo São Cristóvão foi grande rival de Botafogo como área residencial das classes abastadas da cidade. Na década de 1880 usufruía inclusive de vantagens que Botafogo não possuía" 6 . Abreu se refere ao sistema de fornecimento de água e do sistema de esgotos que atendiam ao

\footnotetext{
${ }^{5}$ Ibidem.

${ }^{6}$ Ibidem.
} 
bairro de São Cristóvão. Segadas Soares (1990), analisando a evolução da concepção de subúrbio no Rio de Janeiro, resgata o emprego mais antigo do termo:

Na língua portuguesa, segundo Laudelino Freire, a palavra subúrbio tem o seguinte significado: "arrabaldes ou vizinhanças da cidade ou de qualquer povoação". Esse significado é bem impreciso, mas se formos examinar o emprego mais antigo da palavra, com relação à cidade do Rio de Janeiro, veremos que assim eram chamadas, em meados do século passado, certas áreas como Catumbi, Catete, Botafogo e Gávea, que no quadro administrativo eram consideradas freguesias urbanas, mas que apresentavam aquele aspecto de descontinuidade de construções e de largueza, "de menos gente ocupando mais terra", noção esta, a meu ver, a mais importante, mais permanente e mais generalizada que a palavra contém (SEGADAS SOARES, 1990, p. 139).

O sentido inicial da palavra subúrbio, segundo Segadas Soares, viria a se transformar com a incorporação crescente dos meios de transporte que possibilitaram a expansão da área urbana da cidade, os bondes e trens, "Foi assim, o bonde o primeiro meio de transporte a dilatar a área urbana da cidade, permitindo o adensamento da população fora da área central da cidade e transformando o que até então era chamado de subúrbio, em bairro" (SEGADAS SOARES, 1990, p. 140). A autora destaca o artigo científico de Aureliano Portugal, intitulado "Recenseamento de 1900, no Congresso Científico Latino-Americano", e publicado no Jornal do Comércio em 20 de junho de 1901, onde, segundo ela, estão contidas três noções que vão se ligar "indissoluvelmente" ao conceito carioca de subúrbio, da forma como ele se fixou e permaneceu na linguagem popular, "Essas noções são: o trem como meio de transporte, o predomínio da população menos favorecida de meios de fortuna, e dependência e relações íntimas e frequentes com o centro da cidade" "7. A autora nos esclarece que se a palavra subúrbio já era usada antes da existência do transporte ferroviário para pequenas distâncias (em certas áreas da periferia urbana), ela, porém, só se consagrou e fixou na linguagem popular quando foi associada ao transporte para determinadas áreas de expansão da cidade, servidas por trens com várias viagens diárias.

Nesse sentido, é possível afirmar que as referências espaciais do romance serão revestidas do sentido que o leitor alcançar. A especificidade da narrativa machadiana permite esse diálogo do leitor com o romance. Sobretudo, devemos considerar que o imaginário socioespacial do primeiro momento de recepção do livro, no final do século XIX, é completamente diferente daquele que se desenvolveu depois no século XX. Hoje, passado ainda mais algum tempo, poucas pessoas podem pensar no Engenho Novo como o descreveu Noronha Santos em 1900, ou seja, o diálogo com o romance vai se refazendo à medida que as

\footnotetext{
${ }^{7}$ Ibidem.
} 
referências socioespaciais vão se alterando. Situação semelhante ocorre com a questão que se destacou como central na obra Dom Casmurro, a fidelidade de Capitu. Se, inicialmente, não havia quem duvidasse de sua culpa e do juízo do narrador (José Veríssimo, Lúcia Miguel Pereira, Afrânio Coutinho e Graça Aranha) diante dos indícios apontados no romance (postura que os críticos atribuem ao modelo patriarcal e machista que predominava em nossa sociedade), já no século XX, aos poucos, a interpretação que passou a ganhar peso foi outra, aquela em que Capitu era inocente, e para isso havia do mesmo modo no romance um outro conjunto de indícios que sustentavam essa ideia (CALDWELL, 2008 [1960]).

O Rio de Janeiro que está em Freguesias do Rio Antigo, de Noronha Santos, e aquele que está em Dom Casmurro, de Machado de Assis, refletem a cidade anterior às reformas urbanas segregadoras que terminaram por vincular os subúrbios cariocas a espaços predominantemente proletários. O Rio de Janeiro que viria após as obras de melhoramento das freguesias centrais, que adentram o século $\mathrm{XX}$, mudaria o aspecto da cidade com crescimento demográfico das freguesias suburbanas, como nos fala Maurício Abreu (1987):

Nem todos os que eram expulsos dos cortiços ou que chegavam à cidade localizaram-se, entretanto, nas favelas. A grande maioria, ao que parece, instalou-se nos subúrbios, contribuindo assim para sua ocupação efetiva. Os dados (...) referentes ao período de 1890-1906, parecem confirmar isso, indicando o apreciável aumento populacional ocorrido nas freguesias suburbanas mais próximas do Centro: Engenho Novo e Inhaúma (ABREU, 1987, p. 66).

\section{REFLEXÕES CONCLUSIVAS}

A dimensão espacial da obra de Machado de Assis tem sido uma vertente menos explorada pelos pesquisadores do que as outras que valorizam os processos históricos. $\mathrm{O}$ geógrafo Claudio Duarte (2010) acredita que é possível pensar em um Machado de Assis "geógrafo", conectado a questões espaciais, na mesma medida em que se fala de um Machado "historiador", refletindo questões sociais e políticas de seu tempo. Segundo ele, as mediações sociais e territoriais específicas de um país escravista estão presentes em Machado: "A narrativa machadiana permite-nos reconstruir de modo singular algumas mediações territoriais da cultura e do sujeito brasileiros, que transcendem a simples paisagem ou cenário-mediações, salvo engano, até hoje pouco estudadas" (DUARTE, 2010, p. 64).

A estratégia de compor um "livro falho", para usar a expressão do narrador de Dom Casmurro, na intenção de forçar o leitor a preencher suas lacunas e dar conta de sua incompletude, não se aplicaria somente em relação à culpa ou inocência de Capitu, aspecto até hoje mais explorado do romance. Aspectos referentes a qualificação do ambiente urbano 
são também passíveis de interpretação, como sugere o trecho citado a seguir onde os aspectos referentes à paisagem sejam "completados" pelo leitor, confirmando a necessidade de interação com a obra:

Nada se emenda bem nos livros confusos, mas tudo se pode meter nos livros omissos. Eu, quando leio algum dessa outra casta, não me aflijo nunca. $\mathrm{O}$ que faço, em chegando ao fim, é cerrar os olhos e evocar todas as coisas que não achei nele. Quantas ideias finas me acodem então! Que de reflexões profundas! Os rios, as montanhas, as igrejas que não vi nas folhas lidas, todos me aparecem agora com as suas águas, as suas árvores, os seus altares, e os generais sacam das espadas que tinham ficado na bainha, e os clarins soltam as notas que dormiam no metal, e tudo marcha com uma alma imprevista.

É que tudo se acha fora de um livro falho, leitor amigo. Assim preencho as lacunas alheias; assim podes também preencher as minhas (ASSIS, 2008, p. 995).

Os referenciais qualitativos do subúrbio do Rio de Janeiro manifestam-se de forma sutil na opção de moradia do narrador no Engenho Novo, na intenção confessada inicialmente de fazer do subúrbio o tema gerador do romance, a "História dos Subúrbios", e, ainda, no efeito comparativo dessa suposta obra com as memórias do padre Luís Gonçalves dos Santos (o padre Perereca), que escreveu um relato minucioso sobre a cidade do Rio de Janeiro no início do século XIX para oferecer ao Rei D. João VI. Ao leitor cabe interpretar essas pistas, decifrar esses signos para perceber a dimensão desse espaço na obra e o que ele pode comunicar com o leitor.

Dom Casmurro foi um romance ambientado na cidade do Rio de Janeiro da segunda metade do século XIX, isso é evidente no livro. No entanto, como nos confirmou Veríssimo (1900), não encontramos descrições das paisagens em Machado de Assis, fato que desestimulou por longo tempo os geógrafos que buscavam na obra desse autor uma forma de testemunho ou documento que validasse os estudos regionais. As abordagens da geografia sobre as obras machadianas tiveram mais sucesso com o desenvolvimento da geografia humanista e da corrente cultural, que valorizaram elementos mais subjetivos da relação do autor com o espaço.

Ao longo dessas reflexões, somos levados a procurar a espacialidade do romance Dom Casmurro para além das referências concretas e topológicas da cidade. Diante do leitor, na verdade, abre-se uma lacuna, quando se trata do espaço geográfico nesse romance de Machado de Assis. Porém, não se trata de um vazio ou de uma ausência total de referências, ao contrário, essa lacuna é repleta de significados que instigaram a nossa pesquisa. Somos convencidos de que essa especificidade da dimensão espacial do romance é uma estratégia 
narrativa. Em Dom Casmurro, ao passo que o leitor decide sobre o perfil das personagens, ele termina por ter que fazer algumas considerações ou interpretações sobre a relação delas com a cidade, preenchendo, dessa forma, as lacunas deixadas no texto. Vale ressaltar que o narrador deixa pistas contraditórias sobre sua relação com o espaço, que nos instigam a recompor o imaginário urbano e que deixam brecha para mais de uma interpretação sobre qual Rio de Janeiro, ou ainda, mais precisamente, sobre qual subúrbio o romance quer mostrar.

Para o geógrafo Marc Brosseau (2008, p.426), a ausência de descrição dos lugares não é um obstáculo intransponível à análise geográfica das representações de espaço nos textos literários. Ele garante que, nesse caso, é preciso procurar o espaço por outras pistas. Recorrendo à distinção que Berque estabelece entre topos e chôra, Brosseau argumenta que os geógrafos sempre voltaram suas atenções nos textos literários para o espaço enquanto topos "le lieu observable, décrit, représenté, senti et perçu qui renvoie à un point précis d'un territoire donné" ${ }^{8}$ (BROSSEAU, 2008, p. 424) valorizando as passagens descritivas de um espaço preciso, localizável. Brosseau adverte que, mesmo quando os geógrafos literários querem dar conta de identificar as múltiplas significações e valores atribuídos aos lugares ou às relações entre os espaços e os personagens, numa lógica que ele lembra estar mais associada à ideia de chôra, o desejo do topos é dominante ${ }^{9}$. Tomando a definição de Berque, Brosseau faz a seguinte distinção: "la chôra se distingue du topos dans la mesure ou elle possède um 'caractère attributif': ce qui 'implique souvent la pertinence, l'apropriété du lieu à un certain être ${ }^{10}$ (BROSSEAU, 2008, p. 425 apud BERQUE, 2000, p. 20).

A atração por descrições topológicas precisas foi o que talvez motivou, inicialmente, nessa pesquisa, a suspeita de que os romances e crônicas de Machado de Assis configuravam representações de espaços diversos e específicos, ou seja, estavam respectivamente voltados para as representações de espaços internos e espaços externos da sociedade. Em outras palavras, significava pensar que as salas de visitas das casas e salões de bailes seriam os ambientes que abrigariam predominantemente as tramas dos romances, revelando-se ambientes propícios para representar o espaço do indivíduo, a sua dimensão privada, enquanto que as crônicas, em combinação com a natureza do gênero, estavam representando os espaços externos à casa, na dimensão pública do indivíduo, valendo-se das tramas cotidianas da política, das ruas, do ordenamento territorial urbano. No entanto, após uma análise mais

\footnotetext{
${ }^{8}$ Texto original em francês. Tradução nossa. “o lugar observável, descrito, representado, sentido e percebido que remete a um ponto preciso de um dado território".

${ }^{9}$ Ibidem.

${ }^{10}$ Texto original em francês. Tradução nossa. “ A chora se distingue do topos na medida em que ela possui um caráter atributivo: o que sempre implica a pertinência, a apropriação do lugar a alguém”.
} 
detalhada sobre os espaços nos romances e crônicas do bruxo do Cosme Velho, percebemos que esse aparente arranjo espacial não vai além da primeira aparência. As pesquisas mostraram que esses diferentes gêneros configuravam apenas "entradas" diferentes para o mesmo ambiente. Em outras palavras, constatamos, ao contrário do suposto, que, espaços internos e externos, ou seja, os espaços privados e públicos, constantemente se entremeiam nas tramas, mesmo naquelas de tempo mais curto como a crônica. Tanto os romances quanto as crônicas são ambientados em espaços urbanos complexos, compostos por elementos reais e ficcionais, de temporalidades e escalas espaciais múltiplas, construídos pelo recurso da intertextualidade e com grande correspondência com o imaginário social presente no final do século XIX (composto por mitos e metáforas de modernização da sociedade).

Portanto, a descrição topológica e a localização dos espaços da trama nos romances de Machado, em correspondência com os espaços reais da cidade, não são suficientes para dar conta da complexidade que a dimensão espacial da obra machadiana comporta.

Os espaços das obras de Machado podem ser melhor analisados geograficamente se considerarmos o conjunto das obras e as especificidades narrativas do autor. A dimensão espacial de um romance como Dom Casmurro não se limita somente às paginas do livro, ela se comunica com o conjunto da obra. O Rio de Janeiro de Dom Casmurro corresponde ao espaço cotidiano e turbulento da crônica, à cidade espaço especulativo de Cristiano Palha, em Quincas Borba, e, também, ao espaço dos emergentes Natividade e Santos, pais dos gêmeos, em Esaú e Jacó, romance que surgirá somente em 1904.

Para nós, cabe investigar como a espacialidade é construída, ou se apresenta em um texto construído pelo recurso da intertextualidade. Como realizar uma análise geográfica de um texto construído a partir do diálogo com outros textos, remontando outras escalas temporais e espaciais? O que dizer de Dom Casmurro que, segundo Marta de Senna (2008c), é o romance no qual Machado mais se utiliza desse recurso linguístico, que ela chama no texto "uma estratégia de embuste"?:

Machado de Assis cria esse narrador quase tão bruxo quanto ele, a propornos um desafio a cada leitura, o desafio de, a cada leitura ainda ter embustes a desmascarar. Como o cendal de Camões, a que compara a escumilha com que Capitu nem cobre nem descobre inteiramente os braços, a intertextualidade é mais um véu de que se vale Dom Casmurro, tanto para descobrir quanto para cobrir o sentido desse texto (SENNA, 2008, p. 88).

O resgate da obra de Machado de Assis nesse século e sua patrimonialização pautamse mais na valorização da perspectiva da experiência do autor com o espaço geográfico da cidade, e menos na perspectiva documental da obra. Podemos concluir que a abordagem 
pautada na perspectiva experiencial foi o que possibilitou que a obra pudesse transcender do século XIX para hoje, primeiro porque existe uma vasta fonte documental para desvendarmos a vida urbana carioca do século XIX, e a perspectiva documental também não é um ponto evidente no romance em questão, o que a princípio frustraria tal objetivo; segundo porque a perspectiva da experiência tem uma capacidade enorme de comunicação, uma vez que o leitor se projeta no texto, carregando consigo sua carga experiencial; e, por último, concluímos que a mensagem mais compreendida e imediata sobre os romances machadianos foi aquela que associou a cidade dos romances da fase em que se insere Dom Casmurro à cidade capitalista moderna, aquela com temáticas universais em torno do ciúme, da guerra, da fortuna e da ciência.

As releituras que desvendam no texto as mensagens ocultas são ainda recentes. No que se refere a Dom Casmurro, a dimensão espacial do texto recebe pouca atenção e normalmente tem sido desvinculada da sua dimensão temporal, o que tem contribuído para a superficialidade da leitura geográfica da obra. Dom Casmurro é um romance complexo, que também exige a compreensão de que seus referenciais espaciais não estão ali expostos. As releituras são necessárias, sendo preciso estar-se consciente dos instrumentos teóricos que a Geografia, ao longo de sua relação com a literatura, se valeu para descrever, analisar e interpretar o espaço geográfico.

O romance Dom Casmurro não é uma narrativa que porta características específicas de um certo local ou região, ou que procura evidenciar particularidades de um certo povo ou cultura, ao contrário, ele é uma narrativa que reflete um conflito que poderia se passar em qualquer outra cidade do mundo, sendo exatamente os sentimentos presentes na trama, mundialmente conhecidos, que garantem a dimensão universal do romance. $\mathrm{O}$ recurso da intertextualidade é a marca mais forte do romance Dom Casmurro. É através dele que o autor comunica e constrói o que é, para nós, a representação espacial mais significativa: quando Machado de Assis transpõe a tragédia de Desdêmoda e Otelo para a trama de Bentinho e Capitu, fazendo referência a Otelo, de Shakespeare, ele universaliza o espaço do romance. Sendo assim, o Rio de Janeiro, ao ambientar a trama de Bentinho e Capitu, é remetida a uma escala mais ampla. Talvez essa reflexão possa abrandar a nossa busca por referências topológicas mais exatas no texto.

Através do recurso da intertextualidade, Machado de Assis cria um ambiente que sugere a traição e a tragédia por meio da figura feminina sedutora e traiçoeira. Entre tantos exemplos, as figuras pintadas no teto da casa da Rua de Matacavalos são de personagens da história que teriam sido vítimas de adultério: "Nos quatro cantos do teto as figuras das 
estações, e ao centro das paredes os medalhões de César, Augusto, Nero e Massinissa..." (ASSIS, 2008:932). O episósio do beijo entre Bentinho e Capitu refere-se ao romance Manon Lescaut, personagem feminina que seduz e desvia o jovem Des Grieux, um texto que ficou bastante conhecido no final do século XIX por causa de uma ópera inspirada no romance:

Grande foi a sensação do beijo; Capitu ergueu-se, rápida, eu recuei até a parede com uma espécie de vertigem, sem fala, os olhos escuros (...) Não mofes dos meus quinze anos, leitor precoce. Com dezessete, des Grieux (e mais era Des Grieux) não pensava ainda na diferença dos sexos (ASSIS, 2008, p. 966).

Machado de Assis associa abertamente a tragédia familiar de Dom Casmurro à tragédia de Otelo. Através dessa associação, ele projeta a cidade do Rio de Janeiro numa outra escala, ou seja, como ambiente de uma tragédia shakespeariana. O espaço da ação, nesse caso, aproxima a cidade do Rio de Janeiro dos conflitos universais.

Dessa forma, ao longo do tempo, muitas interpretações não enxergaram uma dimensão geográfica no romance Dom Casmurro exatamente devido às poucas referências espaciais explícitas descritas no livro, até chegarmos ao centenário da morte do escritor, em 2008, e sua consagração como patrimônio cultural carioca, através de um decreto municipal do Rio de Janeiro. A patrimonialização da obra literária de Machado de Assis está inserida num processo de valorização do patrimônio histórico e cultural da cidade. Além de o escritor ter ambientado diversos romances no Rio de Janeiro, ele reúne um grande volume de crônicas que retratam o cotidiano urbano da cidade onde nasceu e passou toda sua vida. Justificativas à parte, isso significa que a dimensão espacial da obra de Machado de Assis, junto com o que isso representa, ou seja, a valorização da carga subjetiva do texto como um elemento importante da experiência com o espaço e de representação espacial, ganha uma evidência maior. Sobretudo, essa condição recai com força sobre Dom Casmurro, o romance de maior prestígio do escritor Machado de Assis.

\section{REFERENCIAS}

ABREU, M. A evolução Urbana do Rio de Janeiro. Rio de Janeiro: IPLAN- RIO/Zahar. 1987.

ASSIS, M. Obra completa em quatro volumes. NETO, A.; CECILIO, A.; JAHN H. Rio de Janeiro: Nova Aguilar, 2008.

BERNARDES, L.; SOARES, T. de S. Rio de Janeiro: Cidade e Região. Rio de Janeiro: Secretaria Municipal de Cultura, 1995. 
BERNARDES, L. M. C. Evolução da Paisagem Urbana do Rio de Janeiro até o Início do Século XX. Boletim Carioca de Geografia 12 (1 e 2), 1959.

BERQUE, A. L'Espace Géographique. Paris: 1984.

. La chôra chez Platon. In: PAQUOT, T.;YOUNÈS, C. Espace et lieu dans la pensée occidentale/de Platon à Nietzache. Paris: La Découverte, 2012.

BROSSEAU, M. Des romans-geographes. Paris: L'Harmattan, 1996.

.L'espace littéraire en l'absence de description: um défi pour l'interpretation géographique de la littérature. Cahiers de géographie du Québec, volume 52, n.147, dez 2008.

CALDWELl, H. O Otelo brasileiro de Machado de Assis. São Paulo: Ateliê Editorial, (tradução Fábio Fonseca de Melo), 2008.

DIMAS, A. Espaço e Romance. São Paulo: Ática, 1986.

DUARTE, C. Iaiá Garcia: poder, sujeito e território no ensaio da "viravolta" machadiana. Machado de Assis em linha, ano 3, n. 5, p.60-75, jun 2010.

GUIMARÃES. H. S. Os leitores de Machado de Assis. O romance machadiano e o público de literatura no século 19. São Paulo: Nankin/ EdUSP, 2004.

LINS, O. Lima Barreto e o espaço romanesco. São Paulo: Ática, 1976.

NORONHA SANTOS, F. A. As Freguesias do Rio Antigo. Rio de Janeiro: O Cruzeiro, 1965.

SCHWARZ, R. Ao vencedor as batatas. São Paulo: Duas Cidades, 1992 [1977].

Um mestre na periferia do capitalismo. São Paulo: Duas Cidades, 1990.

SENNA, M. A bíblia de Mrs. Oswald ou os cochilos do bruxo. Machado de Assis em linha, ano 1, n.1, p. 69-83, jun 2008 a.

Estratégias de embuste: relações intertextuais em Dom Casmurro, [1999]. In SENNA, M. Alusão e zombaria: citações e referências na ficção de Machado de Assis, $2^{\mathrm{a}}$ edição p. 79 - 88, 2008 b.

. Várias histórias na capital imperial [2006]. In SENNA, M. O olhar oblíquo do bruxo: ensaios machadianos. $2^{\mathrm{a}}$ edição, p. 151-167, 2008 c.

VERÍSSIMO, J. História da literatura brasileira: de Bento Teixeira, 1601, a Machado de Assis, 1908. Brasília: Editora Universidade de Brasília, 1961.

Recebido em 15/10/2017.

Aceito em 14/11/2017.

Publicado em 02/01/2018. 